\title{
Material expression of thought
}

Aspects of Ironsmiths in South India

\section{Jan Brouwer}

\section{OpenEdition}

\section{Journals}

Electronic version

URL: https://journals.openedition.org/tc/746

DOI: $10.4000 /$ tc. 746

ISSN: 1952-420X

\section{Publisher}

Éditions de l'EHESS

\section{Printed version}

Date of publication: 1 September 1991

ISSN: 0248-6016

\section{Electronic reference}

Jan Brouwer, "Material expression of thought", Techniques \& Culture [Online], 15 | 1991, Online since 12 January 2006, connection on 29 September 2022. URL: http://journals.openedition.org/tc/746 ; DOI: https://doi.org/10.4000/tc.746

This text was automatically generated on 29 September 2022.

All rights reserved 
Material expression of thought

Aspects of Ironsmiths in South India

Jan Brouwer 